\title{
The French Revolution: The Birth of European Popular Democracy?
}

\author{
RAFE BLAUFARB \\ University of Michigan
}

The French Revolution is generally taken as the advent of European popular democracy. Proclaiming that all public authority derives from the consent of the governed, the revolutionaries reconfigured national and local administration to the principle of popular sovereignty. During the revolutionary decade, in consequence, the French were called upon to vote for their national representatives, local administrators, judicial officials, and ecclesiastics on about twenty occasions. Yet, despite their scope and frequency, revolutionary elections were never the decisive turning points in the political life of the nation that one might expect. Insurrection, civil war, and coups d'état proved more important than elections in determining the course of revolutionary politics. Patrice Gueniffey's pathbreaking study, Le nombre et la raison, seeks to explain why elections were unable to guarantee the peaceful expression of political difference and the smooth transfer of power during the French Revolution. ${ }^{1}$

Gueniffey's work intersects with a broad multi-disciplinary reflection on the question of why democracies succeed or fail. In recent years, this classic problem has received growing attention that seems likely only to increase as fledgling democracies in Eastern Europe and elsewhere falter, and established democracies experience what one author has termed a "malaise."2 The pessimism characteristic of the generation of observers who witnessed the rise of fascism and Soviet-style totalitarianism in Europe and the imposition of military dictatorship or one-party rule in South American and post-colonial states shows little sign of abating as the twentieth century draws to a close ${ }^{3}$ Scholars concerned with these disheartening trends have generally employed two kinds of analysis to explain the difficulties of democracy. One approach

I would like to thank David Bien, Steve Clay, and Melvin Edelstein for their helpful comments on earlier drafts of this essay.

1 Patrice Gueniffey, Le nombre et la raison: La Révolution française et les élections (Paris: 1993).

2 Christopher Lasch, The Revolt of the Elites and the Betrayal of Democracy (New York: 1995), 3 .

3 Seymour Martin Lipset, "Introduction," in Moisei Ostrogorski, Democracy and the Organization of Political Parties, 2 vols. (New Brunswick: 1982), ix.

$0010-4175 / 95 / 3954-3994 \$ 7.50+.10 \subset 1995$ Society for Comparative Study of Society and History 608 
examines the role of a society's political culture in either facilitating or hindering the implantation of democratic practice. The other looks to institutional factors to help explain the success or failure of democracy. Whatever analytic strategy adopted, scholars usually do not interrogate the nature of democracy itself. They take for granted that a consensual understanding exists, defining democracy as the peaceful, electoral competition for power among a variety of groups freely expressing their political opinions in public debate. What is at issue in their analyses is not how different groups have conceived of democracy in the past and present but rather, how political pluralism can be achieved and perpetuated.

In contrast, Gueniffey examines the way democracy was understood historically during the French Revolution. He argues that French Revolutionary democracy failed less because it lacked political acculturation or institutional support than from flaws in the revolutionaries' core assumptions. Through their experience with guilds and village assemblies, the French had a strong popular tradition of collective deliberation and voting. In Revolutionary electoral institutions, the French enjoyed what amounted to universal manhood suffrage and voted by secret ballot. The problems of democracy in the French Revolution, according to Gueniffey, did not arise from cultural or structural weaknesses but from its exclusion of the legitimacy of dissent from its notion of sovereignty. Following the influential interpretation of François Furet, his directeur de thèse, Gueniffey links the revolutionaries' monolithic conception of sovereignty to royal absolutism. According to this argument, the Revolution did not fundamentally alter the nature of sovereignty but, rather, confiscated traditional absolutist authority from the monarchy and vested it in an elected, representative assembly. ${ }^{4} \mathrm{Just}$ as royal power had been undivided and unconstrained, the National Assembly's could countenance neither fragmentation, nor limits, nor opposition. Within this framework, dissent became treason, and opposition became plot. Failing to produce a system of democratic contestation, the French Revolution instead created what one author has termed "parliamentary absolutism."s Gueniffey's work is principally concerned with tracing the negative impact of the revolutionary idea of sovereignty on electoral institutions, voter comportment, and the course of revolutionary politics.

\footnotetext{
${ }^{4}$ Furet sets out his argument in a number of books and articles, the most important of which is Penser la Révolution française (Paris: 1978), translated into English as Interpreting the French Revolution (Cambridge: 1981), Elborg Forster, trans. A more recent expression of his views can be found in La Révolution de Turgot à Jules Ferry, 1770-1880 (Paris: 1988). Furet's ideas have been the subject of much commentary. Some of the most incisive criticism can be found in Lynn Hunt's review of Furet's book, Penser la Révolution française, in History and Theory (20:3 [I98I], 3I3-23).

5 R. Carré de Malberg, Contribution à la théorie générale de l'Etat (Paris: 1962), vol. 2, ch. 2, "Le gouvernement representatif." The citation is from François Furet's preface to Le nombre et la raison, p. vi.
} 


\section{FRENCH REVOLUTIONARY ELECTIONS}

As the first global interpretation of the revolutionary electoral process, Gueniffey's work fills a major gap in the historiography of the French Revolution. Until recently, historians of the French Revolution paid little attention to the electoral process. Gueniffey attributes their puzzling lack of interest to the perception that elections were peripheral to revolutionary politics. Scholars preferred to concentrate on the revolutionary forms of action that had a more visible impact on the course of events between 1789 and 1799. Only when revisionists rejected the classic social interpretation and a new emphasis on the Revolution as a political event emerged did elections begin to receive serious attention from a growing group of international scholars. ${ }^{6}$ For the most part, these historians have studied the sociology of the electorate, geographic patterns of participation, and electoral outcomes in order to track the evolution of the French nation's attitude toward the Revolution. Gueniffey rejects this approach because it has an uncritical acceptance of the democratic "illusion of transparency" (p. I5) that assumes that electoral results mirror the political diversity of society. He claims that elections did not reflect public opinion during the French Revolution because they did not permit the expression of dissent. Le nombre et la raison proposes a provocative explanation for the exclusion of opposition and its results on the democratic process in the Revolution.

Gueniffey begins by examining the effect of the Revolution's conception of sovereignty on its notion of representation. In mid-I 789 the deputies of the Third Estate, bolstered by allies from the clergy and nobility, declared themselves the representatives of the nation and reclaimed sovereignty from the King in the name of the people. Suffrage symbolized the nation's recovery of its fundamental right to obey no authority except that to which it had freely consented. It was, however, impossible for the whole nation to participate directly in government. The size and occupations of the French population required that popular sovereignty be mediated through a system of representation. Yet, since its sovereignty was undivided and absolute, no intermediaries were to stand between the nation and its representatives. Parties and declared candidates could only foster division, and interfere with the direct relationship between the nation and its representation. Accordingly, the people, acting as individuals belonging only to the nation, rather than as members of organic communities, corporate bodies, or parties, would use their suffrage to invest certain citizens with the power to pronounce the general will. Once constitut-

${ }^{6}$ Largely associated with the Institut pour l'Histoire de la Révolution Française and the Atelier: voter et Elire pendant la Décennie Révolutionaire, the French historians working on revolutionary elections include Serge Aberdam, Serge Bianchi, Georges Fournier, Bernard Gainot. Jean-Pierre Jessenne, and Claudine Wolikow. Great Britain and the United States are represented by Malcolm Crook and Melvin Edelstein, respectively. 
ed as a National Assembly, these deputies would speak for the whole nation, rather than any particular constituency. To shield the deputies from the pressures of special interests, the revolutionaries sought to sever the links between the representatives and their constituencies by abolishing all binding mandates and by forbidding the deliberation of electoral assemblies. Revolutionary elections were nothing more than a mechanism for selecting worthy citizens to participate in elaborating the general will, not a way for citizens to express their political opinions or particular interests.

Gueniffey argues that a philosophical contradiction between majority and enlightened rule underlay the revolutionary conception of election. On the one hand, the principle of popular sovereignty militated in favor of extending the vote to all citizens. As sovereign, the whole nation had the right to participate in choosing its representation. In the context of the eighteenth century, such a broad definition of political citizenship had few precedents. The French Revolution, according to Gueniffey, was radical from the outset because it espoused what amounted to universal political rights. Yet, in another way, the revolutionary conception of representation remained conservative, colored by Enlightenment fears about popular democracy. If elections were to function solely according to the logic of numbers, what was to guarantee the proper composition of the representative body and the wisdom of its decisions? To correct the potential for irrationality embodied in a broad franchise, the revolutionaries distinguished between political rights theoretically possessed by all citizens and the right, limited to those who enjoyed higher levels of education and material independence, to exercise political functions.

Gueniffey examines how the revolutionaries attempted to reconcile the contradictory logics of numbers and reason by establishing a two-tiered electoral structure. Cantonal primary assemblies encompassing several parishes formed the base of the system. The principal responsibility of these assemblies was to designate electors to sit on the secondary assemblies, although they also directly named several kinds of local officials. In 1789 , access to the primary assemblies was restricted to active citizens. To qualify as active, one had to be a French male, at least twenty-five years old, be domiciled in a fixed location for one year or more, not be employed as a domestic servant, and pay in taxes the equivalent of three days' wages. Gueniffey takes issue with those historians who have interpreted the conditions required for active citizenship as demarcating a new class of subjects excluded from political rights, the passive citizens. He argues that the revolutionaries conceived of passive citizenship as the temporary suspension of active citizenship. They expected that, as the economic and cultural benefits of the Revolution began to make themselves felt, more and more passive citizens would meet the conditions required of active citizens. The threshold of active citizenship was set so low that it may be plausibly regarded as a prelude to universal manhood suffrage, formally introduced in $\mathbf{I} 792$. 
The most significant distinction within the electorate was not that which divided active from passive citizens but rather that which separated those who could exercise their political rights only in the primary assemblies from their social betters who could be elected to secondary assemblies and public offices, the éligibles. Meeting in the principal city of each département, the secondary assemblies were charged with naming deputies and almost all other public officials. Membership in a secondary assembly was considered a function rather than a right and was consequently granted by the vote of a primary assembly. To be eligible for election to a secondary assembly or another public office, one had to meet the conditions of active citizenship and pay the equivalent of ten days' labor in taxes. These requirements were raised substantially as part of the Feuillant project of halting the Revolution within the limits of the Constitution of 179I. The elevated conditions of eligibility reflected the revolutionaries' belief that only financial independence, education, and a material stake in public order could guarantee responsible decision making. As the Revolution became more egalitarian, however, these wealthbased distinctions appeared increasingly indefensible and in 1792 were abolished altogether. Yet, this change had little practical effect because the two-tiered structure of voting was retained, and the same kinds of people continued to be chosen for secondary assemblies and public offices. The Revolution had created a durable new political class that did not need formal censitary barriers to maintain its position.

At both levels, the electoral assemblies employed a combination of Old Regime corporate and modern individualistic voting procedures. According to Gueniffey, the archaic features of revolutionary electoral systems subverted the realization of the representative ideal of 1789 . This conception required the nation, acting as atomized individuals, to constitute through its unmediated suffrage a truly national representation. Without the radical individualization of the electorate, the vote would reflect community interests rather than the national will. To ensure the individualization of voting, the revolutionaries established electoral circumscriptions larger than the organic community and introduced the secret ballot. The purpose of the first of these innovations was to break the bonds of community at the moment that the vote was cast. The secret ballot served a similar function because it helped voters to follow the dictates of their conscience by freeing them from the surveillance of local notables, patrons, and creditors. The individualization of the vote, however, was subverted because two traditional features of collective decision-takingvoting in assembly and the absence of a clear electoral choice-were retained. The vote in assembly exposed voters to group pressure. The lack of declared candidacies, platforms, and public debate disempowered the individual voter because it denied a real political choice and delivered the outcome of elections to small groups of militants. The effects of this consequential element of revolutionary electoral culture will be pursued at greater length below. 
Postulating a link between the form of electoral mechanisms and voter turnout, Gueniffey traces shifts in the rate of participation across the Revolution. Acknowledging the limitations inherent in the sources used to determine voting patterns, he provides approximate figures which indicate a general trend toward declining participation. From a high of 48 percent achieved in the first revolutionary elections of 1790 , participation fell to 23 percent in I 791 , and then to 15 percent in 1792 , hovering at that level for the rest of the decade. ${ }^{7}$ Gueniffey claims that a high degree of rural participation drove the surge of 1790 . Misled by the familiar practice of voting in assembly, many rural communities mistook the first elections as an opportunity to reclaim communal rights and to reassert collective identities. As countryfolk realized their error, the decline from the initial, promising levels of participation reflected the progressive disengagement of rural France from the Revolution. The constitutional referendum of 1793 , which saw participation rise to $3 \mathrm{I}$ percent, however, diverged from the general trend. Gueniffey attributes this exceptional revival to the return to traditional forms of collective deliberation, as well as the unprecedented mobilization of the electorate by popular societies and government agents. When these procedures were abandoned in the next election, the constitutional referendum of the Year III (I795), participation fell back to levels of about i 8 percent.

Why did so many not vote, and what did their abstention mean? The revolutionaries themselves advanced a number of explanations. Many pointed to the ignorance of their countrymen, the heritage of centuries of absolutism and clerical superstition. Others attributed abstention to the climate of civil strife and fear which pervaded much of the country. Still others noted that the lengthy electoral procedures discouraged citizens from exercising their political rights. Although he recognizes that each of these explanations contained a measure of truth, Gueniffey claims that they all served to divert attention from the political meaning of abstention, thereby allowing revolutionaries to maintain the fiction of a consensus surrounding the Revolution. Examining variations between and within different départements, Gueniffey rejects the notion that regional differences can account for patterns of electoral participation. Rather, he correlates levels of electoral participation to the implantation of political clubs. Abstention was more pronounced in regions lacking a strong Jacobin network, whereas voting patterns were more resistant to the general downward trend in areas with a high density of clubs. Gueniffey argues that the comparatively high levels of participation among populations that fell under the purview of Jacobin clubs did not result from campaigns of voter mobilization. Rather, as the tide of voting receded, Jacobin clubs remained as islands of relatively strong participation in the midst of a population that was largely indifferent or hostile to the Revolution.

${ }^{7}$ Gueniffey derives these figures from a certain amount of original research, as well as the work of other historians, primarily Melvin Edelstein. For a complete breakdown of these findings, see Gueniffey (p. 165). 
Gueniffey concludes that "Jacobinism became the substitute for a people that was henceforth absent (p. 247)."

Abstention was the only way that citizens could express opposition since, revolutionary electoral practice systematically excluded dissent. Political conditions were imposed on participation. Loyalty oaths were demanded of voters during almost every revolutionary election. In some cases, those known to have adopted unpopular political positions were barred from voting. On other occasions, proof of service in the National Guard was demanded of voters. All of these preliminaries were designed to purify the opinion of the electoral assembly before voting had even started, thereby enforcing "explicit adhesion to the orthodoxy of the moment" (p. 257). The most important factor in eliminating opposition in the election process was to do away with public competition between declared candidates representing different viewpoints. Political contestation was illegitimate. The only purpose of elections was to designate worthy individuals who would exercise public authority or participate in pronouncing the general will. An evaluation of moral qualities, rather than a political choice, elections were never intended to be a forum for confronting ideas and working out compromises between opposing groups. Revolutionary election was not supposed to project social divisions onto the political order but, rather, to ensure their exclusion.

Gueniffey argues that the absence of clear electoral choices fatally compromised revolutionary democracy because small groups of militants were unintentionally given the means of achieving electoral success. Although their freedom of choice was theoretically unrestricted, voters had to cast their ballots in a void. They could name almost anyone and often did. The absence of declared candidacies led voters to scatter their suffrage over an absurdly large number of choices. In a 1792 election in Beaune, to give only one example, I67 voters designated no fewer than 103 candidates. This dispersed their votes in such a multitude of improbable candidates that the suffrage of the majority of voters was negated and allowed small groups of activists to form compact blocks of voters, to concert their votes, and to propel their pre-determined candidates to victory. Paradoxically, by defending unlimited freedom of choice, revolutionary electoral mechanisms denied voters an effective political voice. Consequently, according to Gueniffey, revolutionary elections cannot be read as a reflection of majority opinion but rather as a testimony to the ability of local notables and Jacobin clubs to mobilize electoral support for shadowy candidates.

The principal effect of this system was to de-politicize elections. Prevented from serving as a forum for articulating positions by the ban on discussing candidates and on public debate, elections were instead colored by local politics and personalities with only tenuous connections to the national scene. The election of Germinal Year V (March I797) was the exception which proves the rule. Characterized by a high degree of partisan division, it was the only 
revolutionary electoral event to reject the power in place. Gueniffey attributes this result to the electoral regime under which the voting took place. Unlike previous occasions, the election of Germinal Year $\mathrm{V}$ was governed by a new electoral law, adopted on 25 Fructidor Year III ( I I September 1795), which provided for declared candidacies. Though the system of candidacies was still rudimentary, it nonetheless marked a fundamental break with previous conceptions of election. Unlike the earlier revolutionary electoral regimes, this electoral regime recognized the legitimacy of political division and accepted that differences could be worked out by majority rule. Above all, it finally allowed the electorate to voice an effective political opinion by giving it a real choice between candidates and the ideas which they espoused. The new system worked too well for its own good, however, allowing the expression of what Gueniffey terms the "divorce between a majority of the French and the Revolution" ( p. 233). Because this resulted in the massive defeat of the left, anxious directors annulled the election through a military-backed coup and restored a safer electoral regime based on the original regulations of I 789 . These modalities of voting, though allowing the Directory to perpetuate its rule for two more years, cut short the emergence of a pluralistic political space. By demanding loyalty oaths and other signs of adherence to the regime in place, revolutionary electoral systems excluded those with divergent opinions from the political process. By forbidding candidacies, they prevented voters from expressing dissent and delivered public offices into the hands of organized minorities. In Gueniffey's estimation, the failure of the French Revolution to produce a system of election suited to pluralist democracy reflected its "pre-democratic conception of democracy which defined the furthest horizon of revolutionary political culture" ( p. 24).

\section{THE NEW FRONT IN THE DEBATE ABOUT FRENCH REVOLUTION} AND DEMOCRACY

Before offering criticism of this important work, one must first emphasize that it has opened a new front in the debate about the French Revolution and democracy. By advancing such a provocative argument, Gueniffey has invited response from other specialists in the field. Several are already preparing what one has described as a "neo-Jacobin" rebuttal. ${ }^{8}$ Discussion will probably focus on several interpretations central to Gueniffey's argument. The first concerns his equation of voter abstention with opposition. The second is Gueniffey's assertion that regional variations in electoral behavior were insignificant. The third is his contention that voting procedures and abstention allowed minorities to usurp the electoral process. A final subject of debate concerns the possibility that deputies were responsive to their constituents despite formal attempts to detach national representation from local interests. A thorough critique of

\footnotetext{
${ }^{8}$ Malcolm Crook, Melvin Edelstein, and Georges Fournier. The term is Edelstein's.
} 
Gueniffey's sources, methodology, and interpretations must await the forthcoming publications of the scholars working on Revolutionary elections. Until then, the non-specialist reader is left with Gueniffey's basic conclusion: Democracy failed in the French Revolution.

Le nombre et la raison supports François Furet's claims about the essential illiberalism of the French Revolution. Gueniffey provides empirical evidence for Furet's argument by showing how the principles of 1789 tended to subvert liberal democracy. Gueniffey shows how the revolutionaries' monolithic conception of sovereignty, as embodied in electoral institutions and practices, inhibited the expression of dissent, provoked massive abstention, and delivered the political process into the hands of militants. Freed from the checks that a system of democratic contestation provided, the new political personnel could exercise quasi-absolutist authority over France in the name of the sovereign nation. Though it made all public authority elective and instituted something approaching universal manhood suffrage, democracy, Gueniffey concludes, was not a possible outcome of the French Revolution, given that its belief in undivided sovereignty made contestation illegitimate.

Is this view valid? At the end of the eighteenth century were there any popular democracies that accepted the open competition of parties for power as an essential part of the democratic process? Were there any democracies that shared the French view of sovereignty, yet nonetheless eventually managed to produce pluralism? The only comparable contemporary polity was the United States. American democracy shared many of the assumptions of its French counterpart. Most Americans did not believe in the legitimacy of political division. ${ }^{9}$ Madison's pragmatic acceptance of parties (in the tenth Federalist) was a rare exception within a political culture that tended to brand opposition as a foreign plot. Although it never experienced state terrorism (though the emigration of loyalists and the Alien and Sedition Acts came close), terror was a possibility inscribed within the discourse of American democracy. For example, Federalists and Republicans

each saw the other as having a foreign allegiance, British or French, that approached the edge of treason. Each also saw the other as having a political aspiration or commitment that lay outside the republican covenant of the Constitution: the Federalists were charged with being "Monocrats," with aspiring to restore monarchy and the hereditary principle; the Republicans with advocating a radical French-inspired democracy hostile to property and order. ${ }^{10}$

9 "Those who built the first political party system in the I790's mistook parties for factions, assuming that those with whom they differed were disloyal to the nation and its ideals. . . The first parties were confused with factions because the modern political party was outside the range of this generation's experience as well as its historical consciousness" (Paul Goodman "The First American Party System" in William Nisbet Chambers and Walter Dean Burnham, eds. The American Party Systems: Stages of Political Development [New York: 1967], 90).

10 Richard Hofstadter, The Idea of a Party System: The Rise of Legitimate Opposition in the United States, 1780-1840 (Berkeley: 1970), 90. 
The acceptance of political contestation emerged only by trial and error, in fits and starts, and unevenly in the different states of the Union. If pluralism was not the product of a deliberate program but only emerged gradually over a period of decades, perhaps the failure of the French Revolution to move toward accepting the legitimacy of opposition can be attributed to the difficult circumstances in which it was forced to construct and implement France's first democracy. ${ }^{11}$ Torn by war, factionalism, religious strife, and fiscal crisis, France never had the time to experiment with pluralism, a risky enterprise even in a relatively stable society like the United States.

Gueniffey overemphasizes the extent to which the ideal of undivided sovereignty, rather than the political context of the Revolution, engendered "parliamentary absolutism." He attributes the deputies' repudiation of their binding mandates in 1789, the act that formally severed the links between them and their constituents, to their belief that the national will must not be fragmented by the consideration of particular interests. The deputies' action, however, was determined less by the logic of their principles than by the structure of the National Assembly. One must not forget that the deputies had originally been chosen to represent distinct social orders and that their mandates expressed the desires of the Old Regime estates and corporations. To have recognized the validity of the mandates in mid- 1789 would have been tantamount to confirming the legitimacy of the society of orders and abandoning the Revolution's dream of a new polity. The creation of a national representation cut off from its constituents resulted less from the idea of undivided sovereignty than from a pragmatic attempt to deal with the uncomfortable fact that the deputies of the National Assembly represented a social order that was no more. If the mandates had not been abolished or new elections had not taken place, the National Assembly would have remained the Estates-General. ${ }^{12}$

Can the failure of French Revolutionary democracy be explained in terms of an essentially anti-democratic logic embedded in its fundamental principles? This view implies the existence of a distinct body of fundamental beliefs and suggests that the range of ideas available to the early Revolution possessed a unity that in fact did not exist. Until at least early 1790 , debates and political pamphlets were full of opinions which seem absurdly out of touch with what became mainstream Revolutionary ideology. Yet, these ideas appear unrealistic only because we know where the Revolution went and because we can identify the fundamental lines of its thought that did not lead to a dead end but persisted

11 On the "thesis of circumstances," see Donald Sutherland, "An Assessment of the Writings of François Furet," French Historical Studies, I6:4 (I990), 784-9I; and Isser Woloch "On the Latent Illiberalism of the French Revolution," American Historical Review, 95:5 (1990), I45270.

12 On the problem of reaching decisions by voting in a National Assembly composed of deputies who had formerly represented the society of orders, see David D. Bien, "François Furet, the Terror, and 1789," French Historical Studies, 16:4 (1990), 777-83. 
as the Revolution caused drastic change. Revolutionary politicians and writers, however, did not have the advantage of hindsight. The naiveté of many of their ideas suggests that there was a wide range of possibilities contained in the early Revolution and that no one foresaw which would prevail. As historians, our two-fold task is to reconstruct the range of understandings and options available to the historical actors and to ask why certain tendencies gained in strength while others declined.

To his credit, Gueniffey acknowledges that alternative conceptions of the democratic process existed in 1789 . He discusses at length the handful of political writers (including Brissot) who envisaged the creation of a system of democratic contestation by legalizing candidacies and public debate. Even if only a minority of political thinkers accepted the legitimacy of political competition in the beginning of the Revolution, Gueniffey notes that attitudes changed with time and experience. The first electoral law of the Directory incorporated elements of this nascent pluralism. When finally applied in the elections of the Year $\mathrm{V}$, the new system worked, allowing a powerful opposition to take shape in the legislature. Only the Directors' hunger for power-expressed through their coup of I 8 Fructidor-prevented the new democratic experiment from receiving a fair trial. If the Directors had accepted the results of the consultation and stepped down, the idea of legitimate opposition and the peaceful transfer of power through elections might have taken root in France. By expanding his focus to include those ideas that did not win immediate acceptance in 1789 and by extending his chronological scope beyond the period between 1789 and I 793, Gueniffey himself brings forth evidence which tempers his argument that the Revolution's failure to produce democracy was inscribed in its core political assumptions. 